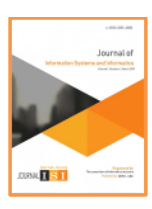

Vol. 3, No. 1, March 2021 e-ISSN: 2656-4882 p-ISSN: 2656-5935

\title{
Strategy of Indonesian Navy Big Data Development Using SWOT Analysis and Analytic Hierarchy Process
}

\author{
Aria Cakra Wibawa ${ }^{1}$, Bambang Suharjo ${ }^{2}$ \\ ${ }^{1}$ Indonesian Navy Information and Data Processing Services, Jakarta, Indonesia \\ 2 Mathematics Department, Indonesian Defence University, Indonesia \\ Email:1 aria3690@gmail.com, 2bambang_suharjo@tnial.mil.id
}

\begin{abstract}
The Indonesian Navy organization has the duties and responsibilities of state sovereignty. In carrying out its duties are needed very large and real time data include data on ships in all Indonesian waters from satellite and terrestrial AIS, from radar, data from long range cameras, data from other agencies such as weather data, marine accident data, natural disasters data and fishing areas data. The managed data are consists of structured, semi-structured and unstructured data. Thus, big data is needed within the Indonesian Navy. Therefore, this study analyzes the strategies that need to be taken to be able to develop a big data in the Indonesian Navy. The method used is qualitative analytic research using SWOT and AHP. The research subjects were Head of Section at Command and Control Center, and Head of Section at Information and Data Processing Services. The resulting main strategy is to implement Big Data with existing and adequate system resources, manageable costs, set up network infrastructure and sufficient bandwidth using available big data software by optimizing government regulations regarding single data for communication and data sharing from other agencies and optimizing advanced API technology.
\end{abstract}

Keywords: Indonesian Navy, Strategy, Big Data, SWOT, AHP

\section{INTRODUCTION}

The Indonesian Navy is a large organization, with duties and responsibilities for the safety and sovereignty of the state as stated in Article 9 of the Republic of Indonesia Law Number 34 of 2004. In the implementation of its duties and activities management the Indonesian Navy has and requires very large data and must be managed. Most of the data in the surveillance and control of maritime security and sovereignty is very large and must be real time. Various data needed in supervision and control of the sea. Data from various other agencies in real time are also required to support the analysis. The data needed includes data on ships sailing in real time in Indonesia in real time obtained from the satellite and 
terrestrial Automatic Information System (AIS), data from radar, data from long range cameras, data from other agencies such as data weather from the Meteorology, Climatology and Geophysics Agency in real time, data from the National Search and Relief Agency in real time, data on natural disasters such as earthquakes that occur in real time as well as from the National Disaster Management Agency, data fishing areas and data on fishing vessels sailing in Indonesia in real time from the Ministry of Marine Affairs and Fisheries. The data types to be managed include structured data, such as marine and shipping databases, semi-structured data which are json data from other ministries and satellite AIS and unstructured data which includes data from long range cameras and radars.

Based on discussions with the Indonesian Navy Data Center team, it can be concluded that the existing database system is no longer adequate to use, because it only includes structured data so that it cannot accommodate existing semistructured and unstructured data. On the other hand, Big Data has the advantage of being able to accommodate all kinds of data and in large quantities. Big data analytics as a method for looking at big data to reveal hidden patterns, incomprehensible relationships, and other important data that can be used to resolve improved decisions. Big data continues to grow for big data because of its fast development and because it covers different application areas ((Memon et al., 2017). Big data development requires large amounts of resources and funds. Various challenges faced in big data management include data availability, data standardization, data privacy, infrastructure and human resources ((Sirait, 2016). These challenges are of course also faced by the Indonesian Navy in pursuing the development of big data implementation. Thus, the Indonesian Navy's big data development strategy is needed. analyze how the strategies that need to be taken to be able to develop big data in the Indonesian Navy.

\section{METHODS}

\subsection{Location and Time of Research}

This research was conducted in the Indonesian Navy Command and Control Center and the Indonesian Navy's Information and Data Processing Service, because Command and Control Center is an office that manages the implementation of the main data for the Indonesian Navy in order to carry out operations and tasks of the Indonesian Navy. Meanwhile, Information and Data Processing Service is tasked with planning, developing, and maintaining all information systems in the Indonesian Navy. The research was conducted in November and December 2020. In November 2020, data collection, data processing and analysis were carried out and research report writing was carried out in December 2020. 


\subsection{Data and Subject of Research}

The data to be managed is data on the strengths and weaknesses of the Indonesian Navy in the development of the Big Data system, as well as opportunities and threats outside the Indonesian Navy that must be overcome and anticipated. Based on these needs, this study used qualitative methods to obtain this data through structured interviews combined with expert opinions to be managed with analytic hierarchical process (AHP) for weighting and rating. The research subjects were Intermediate Officers level at the Command and Control Center and Information and Data Processing Service. In detail, there are 3 heads of Command and Control Center Sections, 11 Heads of Information and Data Processing Service Sections. They play a role in filling structured interviews and become experts in determining weights with AHP.

\subsection{Data Analysis Technique}

Data analysis was carried out by the following steps.

1. Formulation of Strengths and Weaknesses, Opportunities and Threats

Data collection used structured interview guides. The results are collected and then analyzed using content analysis which includes four main stages, namely: decontextualization, recontextualization, categorization, and compilation (Bengtsson, 2016). Furthermore, the technique of compiling strengths and weaknesses, opportunities and threats in the content analysis process is carried out, dependability analysis is carried out to obtain reliable opinions from research subjects in accordance with triangulation as a powerful technique that facilitates data reliability through triangulation or cross-verification of two or more sources (Johnson, 2017). So that each item that is concluded about strengths, weaknesses, opportunities and threats has been believed to be valid and reliable.

2. Compilation of weights and ratings

Weights and ratings are compiled after compiling items of strengths, weaknesses, opportunities and threats. The technique used is to gather expert opinion, in this case 3 Heads of Command and Control Sections, 11 Heads of Information and Data Processing Services Sections. The technique used is the AHP technique, namely by making pairwise comparisons and looking for the weight of each item on these factors according to the AHP step (Oreski, 2012).

3. Strategy Formulation

Furthermore, strategy formulation is carried out by calculating the SWOT matrix which is equipped with weights and ratings to develop S-O, W-O, S-T, and $\mathrm{W}-\mathrm{T}$ strategies. 


\subsection{Flowchart Diagram}

Based on these data analysis techniques, a research flow chart can be prepared as follows.

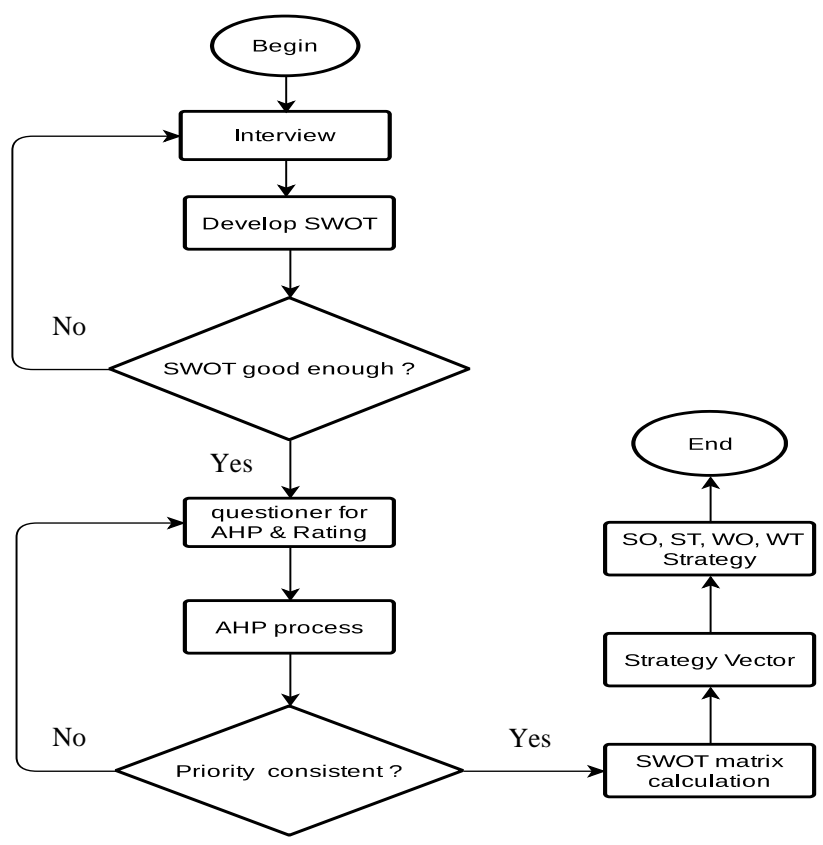

Figure 1. Research Flowchart

\section{RESULTS AND DISCUSSION}

\subsection{Analysis of Strengths, Weaknesses, Opportunities and Threats}

The analysis of strengths, weaknesses, opportunities and threats which is the S-W$\mathrm{O}-\mathrm{T}$ analysis was carried out using data collection using structured interviews on research subjects consisting of 3 Heads of Command and Control Center Sections, 11 Heads of Information and Data Processing Service Sections. Data processing using qualitative data analysis techniques. Using content analysis with steps of decontextualization, recontextualization, categorization, and compilation as well as through triangulation of questionnaire results for all respondents to adjust the SWOT placement and obtain meaning from the data collected and draw realistic conclusions. The results of data processing from research subjects produce strengths, weaknesses, opportunities and threats as follows. 
Vol. 3, No. 1, March 2021

p-ISSN: 2656-5935 http://journal-isi.org/index.php/isi $\quad$ e-ISSN: 2656-4882

Table 2. Results of Strength, Weakness, Opportunity and Threat Analysis

\begin{tabular}{|l|l|}
\hline Strength & $\begin{array}{l}\text { a. The management of the Indonesian Navy's information system is a } \\
\text { mixture of centralized and decentralized which is well organized } \\
\text { b. Funding is organized in a systemic and open manner which allows for } \\
\text { comprehensive planning } \\
\text { c. The network infrastructure is neat } \\
\text { d. Internet bandwidth has become more evenly distributed }\end{array}$ \\
\hline Weakness & $\begin{array}{l}\text { a. Lack of human resources in the field of information technology } \\
\text { b. HR competencies in information technology are not up to date with the } \\
\text { new big data-based system }\end{array}$ \\
c. Not all of the security of the TNI AL network is guaranteed, especially \\
those outside the TNI AL cloud \\
d. Many applications are still not integrated with different platforms
\end{tabular}

\subsection{Analysis of Weight, Rating and Strategy}

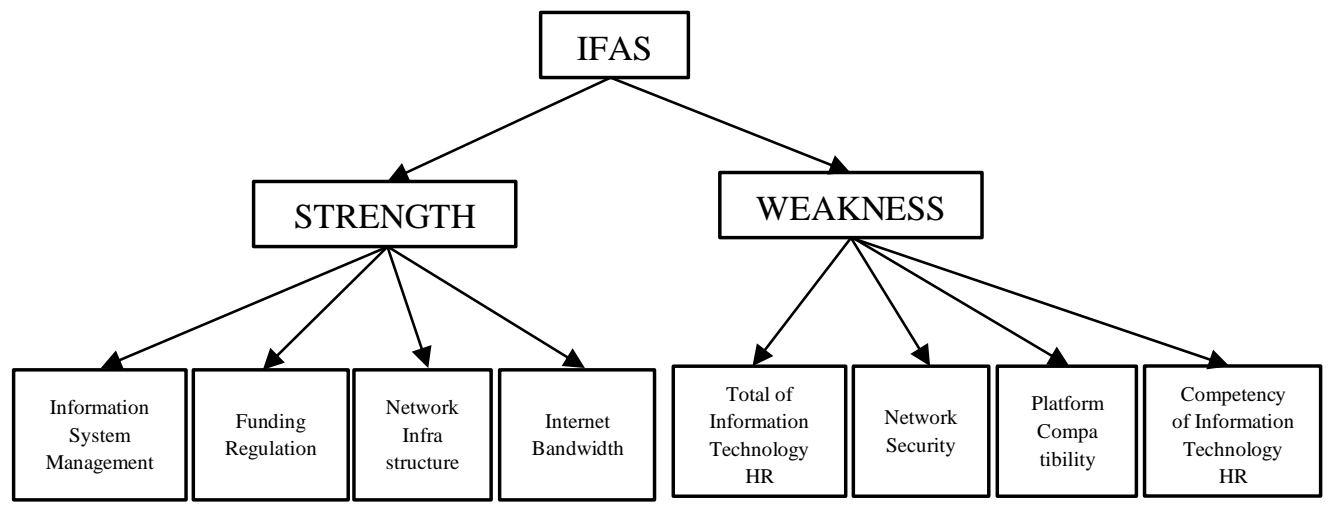

Figure 1. AHP IFAS 
Vol. 3, No. 1, March 2021

p-ISSN: 2656-5935 http://journal-isi.org/index.php/isi e-ISSN: 2656-4882

The weight and rating analysis was carried out as with the help of the Analytic Hierarchy Process application. Data from research subjects who are also experts in the field of information technology and its use within the Indonesian Navy. Each research subject filled out a pairwise comparison questionnaire based on the level of importance. Then the pairwise comparison results are averaged with a geometric mean and input into the Super Decision application to calculate the weight, as follows. Furthermore, the output of calculating the weight of each indicator on the internal factors including strengths and weaknesses is presented as follows.

Table 3. Weights of strengths and weaknesses

\begin{tabular}{|l|c|}
\hline \multicolumn{1}{|c|}{ Strength Indicators } & Weight \\
\hline Internet bandwidth & 0.14 \\
\hline Network Infrastructure & 0.07 \\
\hline Funding regulation & 0.12 \\
\hline Information System Management & 0.17 \\
\hline \multicolumn{1}{|c|}{ Weakness Indicators } & Weight \\
\hline Total of Information Technology HR & 0.10 \\
\hline Network Security & 0.12 \\
\hline Platform compatibility & 0.10 \\
\hline Competency of Information Technology HR & 0.17 \\
\hline
\end{tabular}

The results of these calculations are obtained with an inconsistency level of 0.035. The inconsistency value is less than 0.1 . So, it can be said that the results of the weight calculation are consistent. Furthermore, for EFAS analysis, the weight calculation is carried out using the AHP model as follows.

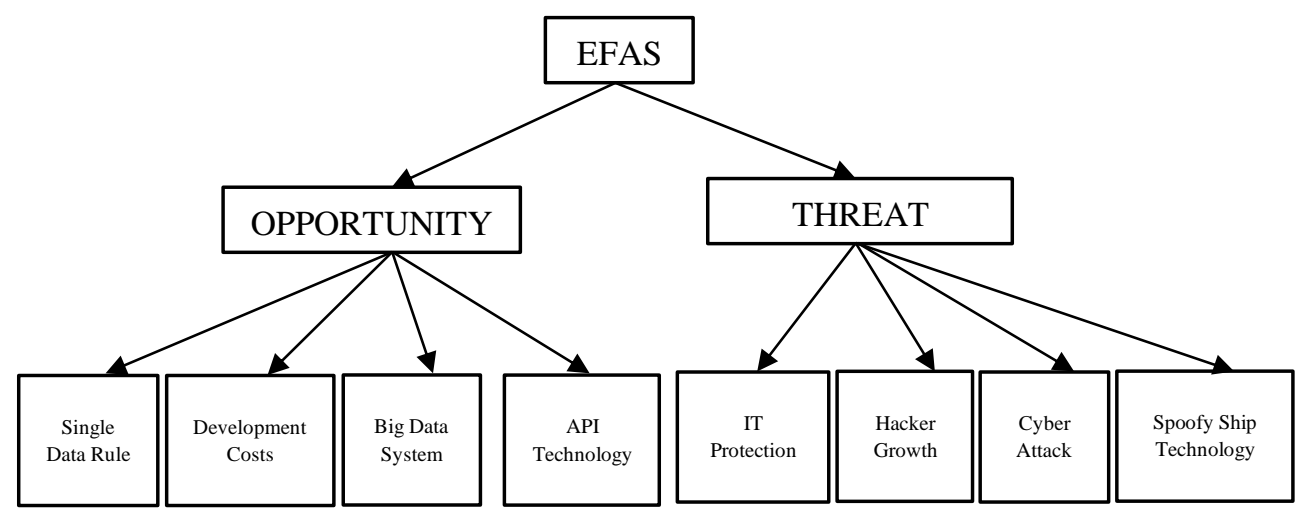

Figure 2. AHP EFAS 
Vol. 3, No. 1, March 2021

p-ISSN: 2656-5935 http://journal-isi.org/index.php/isi e-ISSN: 2656-4882

Furthermore, the output of calculating the weight of each indicator on the external factors including strengths and weaknesses is presented as follows.

Table 4. Weights of opportunities and threats

\begin{tabular}{|l|c|}
\hline \multicolumn{1}{|c|}{ Opportunity Indicators } & Weight \\
\hline Single data rule & 0.07 \\
\hline Development costs & 0.10 \\
\hline Big data system & 0.20 \\
\hline API technology & 0.13 \\
\hline \multicolumn{1}{|c|}{ Threat Indicators } & Weight \\
\hline IT protection & 0.07 \\
\hline Hacker growth & 0.09 \\
\hline Cyber attack & 0.12 \\
\hline Spoofy ship technology & 0.22 \\
\hline
\end{tabular}

The results of these calculations are obtained with an inconsistency level of 0.0806 . The inconsistency value is less than 0.1 . So, it can be said that the results of the weight calculation are consistent. Furthermore, the weight calculation results are equipped with a rating obtained from the opinion of the respondents in accordance with the average rounding with a rating of 1 to 10 , as presented in the final calculation results as follows.

Table 5. Weight Calculation Results and Ratings for Strengths, Weaknesses,

Opportunities and Threats

\begin{tabular}{|c|l|c|c|c|}
\hline \multirow{5}{*}{ FACTORS } & \multicolumn{1}{|c|}{ INDICATORS } & WEIGHT & RATING & $\begin{array}{c}\text { WEIGHT } \\
\text { x RATING }\end{array}$ \\
\hline \multirow{5}{*}{ Strengths } & $\begin{array}{l}\text { Information system } \\
\text { management system }\end{array}$ & 0.17 & 6.5 & 1.105 \\
\cline { 2 - 5 } & Funding Arrangement & 0.12 & 7.2 & 0.864 \\
\cline { 2 - 5 } & Network infrastructure & 0.07 & 8.1 & 0.567 \\
\cline { 2 - 5 } & Internet bandwidth & 0.14 & 6.9 & 0.966 \\
\hline \multirow{5}{*}{ Weaknesses } & Total IT HR & 0.1 & -5.1 & -0.51 \\
\cline { 2 - 5 } & IT HR competencies & 0.17 & -4.3 & -0.731 \\
\cline { 2 - 5 } & $\begin{array}{l}\text { Indonesian Navy network } \\
\text { security }\end{array}$ & 0.12 & -3 & -0.36 \\
\cline { 2 - 5 } & $\begin{array}{l}\text { Application platform } \\
\text { compatibility }\end{array}$ & 0.1 & -3.9 & -0.39 \\
\hline & & 0.2 & 7.8 & -1.991 \\
\hline \multirow{5}{*}{ Opportunities } & Big Data Systems & 0.1 & 6.9 & 0.69 \\
\cline { 2 - 5 } & Development Costs & 0.07 & 8.1 & 0.567 \\
\cline { 2 - 5 } & $\begin{array}{l}\text { Government rules on single } \\
\text { data }\end{array}$ & & & \\
\hline
\end{tabular}


Vol. 3, No. 1, March 2021

p-ISSN: 2656-5935 http://journal-isi.org/index.php/isi e-ISSN: 2656-4882

\begin{tabular}{|l|l|c|c|c|}
\multirow{5}{*}{} & API technology & 0.13 & 7.8 & 1.014 \\
\hline \multirow{4}{*}{ Threats } & & & & 3.831 \\
\hline \multirow{5}{*}{} & Cyber attack & 0.12 & -4.1 & -0.492 \\
\cline { 2 - 5 } & Ship spoofy technology & 0.22 & -5.3 & -1.166 \\
\cline { 2 - 5 } & Hacker Growth & 0.09 & -5.9 & -0.531 \\
\cline { 2 - 5 } & $\begin{array}{l}\text { ITE protection rules between } \\
\text { countries }\end{array}$ & 0.07 & -3.1 & -0.217 \\
\hline & & 1 & & -2.406 \\
\hline
\end{tabular}

Based on the results of the analysis, then a strategy matrix is developed which is the coordinate of the Strength - Opportunity (SO) vector is $(3.502 ; 3.831)$, the coordinate of the Strength - Threat (ST) vector is $(3.502 ;-2.406)$, the WeaknessOpportunity coordinate is $(-1.991) ; 3,831)$, and the Weakness-Threat coordinates are $(-1.991 ;-2.406)$. Based on these results, the resultant vector coordinates can be compiled, namely: (3.502 - 1.991; 3.831-2406) or equal to (1.511; 1.425). Furthermore, vectors can be arranged in Cartesian coordinates as follows.

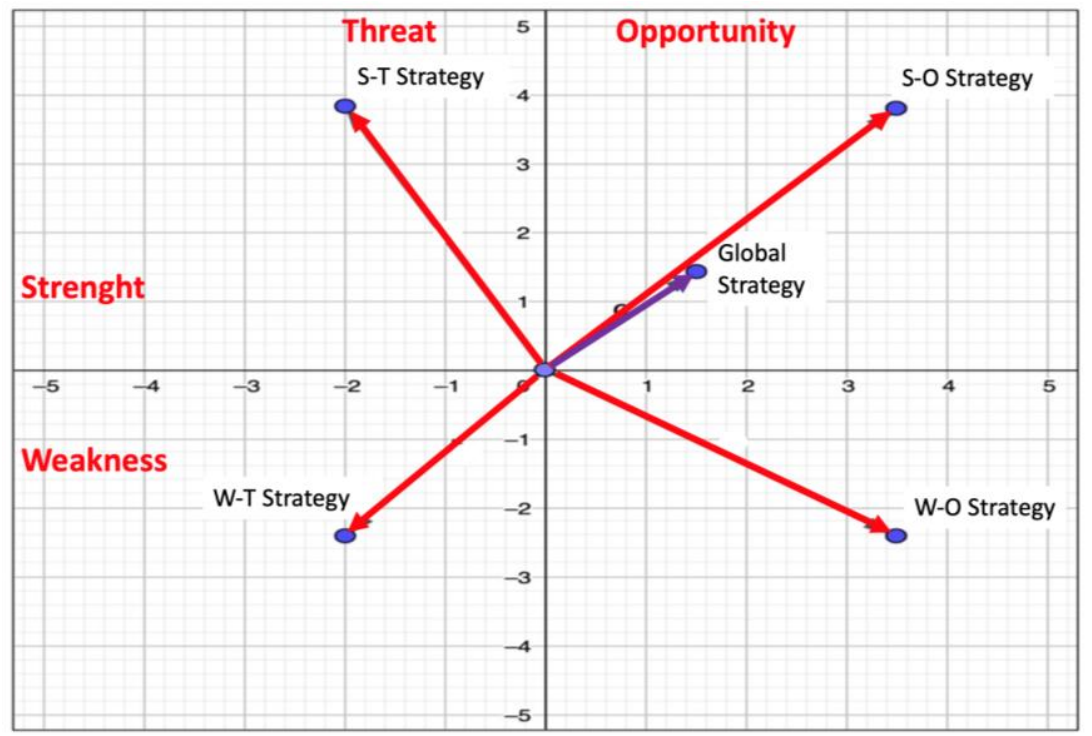

Figure 3. Vectors of SWOT strategy

From the calculation of the matrix, it appears that there are 4 strategic directions that can be developed. As well as the resultant strategy leading to an offensive strategy that will take advantage of many opportunities with the strength of the Indonesian Navy. Based on the results of the matrix calculation above, a detailed SO, ST, WO, and WT strategy and a combined strategy were developed. The results are as follows. 
Vol. 3, No. 1, March 2021

p-ISSN: 2656-5935 http://journal-isi.org/index.php/isi

e-ISSN: 2656-4882

Table 6. List of S-O strategies, W-O strategies, S-T strategies, and W-T strategies

\begin{tabular}{|c|c|c|}
\hline & 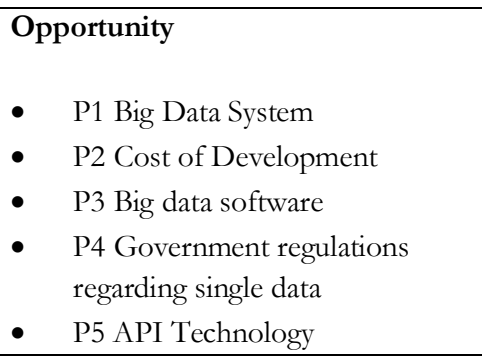 & $\begin{array}{l}\text { Threat } \\
\text { - } \quad \text { T1 Cyber attack } \\
\text { - } \quad \text { T2 Ship spoofy technology } \\
\text { - } \quad \text { T3 Hacker Growth } \\
\text { - } \quad \text { T4 IT protection rules } \\
\text { between countries }\end{array}$ \\
\hline Strength & S-O Strategy & S-T Strategy \\
\hline $\begin{array}{l}\text { - S1 Information } \\
\text { System } \\
\text { Management } \\
\text { System } \\
\text { - S2 Costing } \\
\text { Arrangement } \\
\text { - S3 Network } \\
\text { infrastructure } \\
\text { - S4 Internet } \\
\text { bandwidth }\end{array}$ & $\begin{array}{l}\text { Implement Big Data with existing and } \\
\text { adequate system resources, } \\
\text { arrangements for costs that can be } \\
\text { made, well-organized network } \\
\text { infrastructure and sufficient } \\
\text { bandwidth using the available big data } \\
\text { software to optimize government } \\
\text { regulations on single data when } \\
\text { communication and data sharing from } \\
\text { agencies are required. others and } \\
\text { optimizing advanced API technology. }\end{array}$ & $\begin{array}{l}\text { Managing information systems, } \\
\text { financing arrangements, network } \\
\text { infrastructure and existing } \\
\text { internet bandwidth to deal with } \\
\text { cyber attacks, developing ship } \\
\text { spoofing technology, hacker } \\
\text { attacks even though there are no } \\
\text { rules for protecting IT between } \\
\text { countries because basically } \\
\text { internet technology can cover } \\
\text { between countries so that it } \\
\text { allows more freedom of } \\
\text { protection }\end{array}$ \\
\hline Weakness & W-O Strategy & W-T Strategy \\
\hline $\begin{array}{l}\text { - W1 Total IT HR } \\
\text { - W2 IT HR } \\
\text { Competencies } \\
\text { - W3 Indonesian } \\
\text { Navy network } \\
\text { security } \\
\text { - W4 Application } \\
\text { platform } \\
\text { compatibility }\end{array}$ & $\begin{array}{l}\text { Optimizing collaboration with other } \\
\text { agencies in accordance with big data } \\
\text { rules to dominate human resource } \\
\text { shortages, competence and network } \\
\text { security that need to be overcome and } \\
\text { the suitability of various platforms that } \\
\text { can be overcome with big data } \\
\text { technology that accommodates } \\
\text { multiplatform and takes advantage of } \\
\text { developed API technology. }\end{array}$ & $\begin{array}{l}\text { Manage carefully with high } \\
\text { vigilance by paying attention to } \\
\text { the security of the Indonesian } \\
\text { Navy's network and applications } \\
\text { according to their respective } \\
\text { platforms from cyber threats, } \\
\text { ship spoofy technology, hackers } \\
\text { and protecting against ITE } \\
\text { protection rules between } \\
\text { countries that don't yet exist. }\end{array}$ \\
\hline
\end{tabular}

Based on the results of the strategy analysis, a grand strategy for the Indonesian Navy Big Data strategy that is more offensive can be arranged according to the results of the vector calculation, which is $\mathrm{S}-\mathrm{O}$ with a score of $(2,4 ; 2,7)$ as follows. Implementing Big Data with existing and adequate system resources, managing costs that can be done, well-organized network infrastructure and sufficient bandwidth using available big data software to optimize government regulations 
regarding single data when communication and data sharing from agencies are required. others and optimizing advanced API technology while still paying attention to the WO, ST, and WT strategies, namely:

a. optimizing cooperation with other agencies in accordance with big data rules to eliminate human resource shortages, competence and network security that need to be overcome and the suitability of various platforms that can be overcome with big data technology that accommodates multiplatform and takes advantage of developed API technology.

b. Managing information systems, financing arrangements, network infrastructure and existing internet bandwidth to deal with cyber attacks, developing ship spoofing technology, hacker attacks even though there are no rules for protecting IT between countries because basically internet technology can cover between countries so that it allows more freedom of protection

c. Manage carefully with high vigilance by paying attention to the security of the Indonesian Navy's network and applications according to their respective platforms from cyber threats, ship spoofy technology, hackers and protecting against IT protection rules between countries that don't yet exist.

This strategy is in accordance with the strategies developed in IT companies as carried out by Aneato (2020), namely communication, training, employee involvement in decision making, and teamwork strategies. Here the similarity in communication is an effort to eliminate weaknesses and use opportunities in the form of rules for one data and data required from other agencies. The strategy developed to establish communication and cooperation with other agencies is also in line with the results of research by Heriyadi et al (2017) that the problem of national defense is not only the task and responsibility of Military, but also the duties and responsibilities of all components of the nation. So that Big data is developed in a national big data ecosystem which is in line with research in the Indian Navy (Kulshrestha, 2017). Thus, it is believed that the strategy developed has found relevance and suitability with the IT world in general and the military in particular.

\section{CONCLUSION}

Based on the results of the calculations and discussion above, it can be concluded that by using SWOT and AHP, the main strategy for the Indonesian Navy's Big Data can be developed, namely implementing Big Data with existing and adequate system resources, managing costs that can be done, and well-organized network infrastructure. and sufficient bandwidth using the available big data software to optimize government regulations on single data when it requires communication and data sharing from other agencies and optimizing advanced API technology. 
The main strategy needs to be supported by: first, keeping in mind the optimization of cooperation with other agencies in accordance with regulations, to eliminate shortages of human resources, competence and network security as well as the suitability of various platforms with big data technology that accommodates multiplatform and utilizes already developed API technology. Managing information systems, financing arrangements, existing network infrastructure and internet bandwidth to deal with cyber-attacks, ship spoofing technology, hacker attacks even though there are no IT protection rules between countries because basically internet technology can cover between countries so that it allows more flexible protection. Manage carefully with high vigilance by paying attention to the security of the Indonesian Navy's network and applications according to their respective platforms from cyber threats, ship spoofy technology, hackers and protecting against IT protection rules between countries that don't yet exist.

\section{REFERENCES}

[1] Aneato, D. (2020). Strategies to Implement Big Data Analytics in Telecommunications Organizations. Walden Dissertations and Doctoral Studies. Diakses dari https://scholarworks.waldenu.edu/dissertations

[2] M. A. Memon, S. Soomro, A. K. Jumani, and M. A. Kartio, "Big data analytics and its applications," Ann. Emerg. Technol. Comput., vol. 1, no. 1, pp. 45-54, 2017, doi: 10.33166/AETiC.2017.01.006.

[3] E. R. E. Sirait, "Implementasi Teknologi Big Data Di Lembaga Pemerintahan Indonesia," J. Penelit. Pos dan Inform., vol. 6, no. 2, p. 113, 2016, doi: 10.17933/jppi.2016.060201.

[4] B. Jibai, H. Alaaraj, and A. Issa, "Developing SWOT/ TOWS Strategic Matrix for E-Banking in Lebanon," Int. Bus. Account. Res. J., vol. 2, no. 1, pp. 13-21, 2017, doi: 10.15294/ibarj.v2i1.27.

[5] A. B. Citta, A. Ridha, Y. A. Dekrita, and R. Yunus, "Advances in Economics, Business and Management Research (AEBMR), volume 92," Adv. Econ. Bus. Manag. Res., vol. 92, no. Icame 2018, pp. 119-126, 2019.

[6] D. Aneato, "Strategies to Implement Big Data Analytics in Telecommunications Organizations Walden University," 2020.

[7] S. Kulshrestha, "Big Data Analytics in Indian Navy," pp. 0-4, 2017.

[8] Desclaux, "Lt Gen ( Ret ) Gilles DESCLAUX' s Keynote at IST 160 Specialists ' Meeting BIG DATA \& ARTIFICIAL INTELLIGENCE FOR MILITARY DECISION MAKING," 2018.

[9] Heriyadi, Z. Fanani, S. Widagdo, and A. Hariswanto, "Swot Analysis of National Defence System To Face Infromation War in Digital Era.," Int. J. Adv. Res., vol. 7, no. 5, pp. 457-463, 2019, doi: 10.21474/ijar01/9059.

[10] A. K. Susilo and B. Pramono, "THE DEVELOPMENT STRATEGY FOR EMPOWERING THE DEFENSE AREA OF A NONMILITARY ASPECT IN,” J. Def. Resour. Manag., pp. 195-221, 2020. 
[11] M. Bengtsson, "How to plan and perform a qualitative study using content analysis," NursingPlus Open, vol. 2, pp. 8-14, 2016, doi: 10.1016/j.npls.2016.01.001.

[12] H. Johnson, "Understanding the Role of Triangulation in Research," Sch. Researh J. Interdiscipinary Stud., vol. 6, no. 177, pp. 91-95, 2017, [Online]. Available: $\quad$ http://www.srjis.com/pages/pdfFiles/149544238718. HONORENO JOHNSON.pdf.

[13] D. Oreski, "Strategy development by using SWOT-AHP," TEM J., vol. 1, no. 4, 2012. 